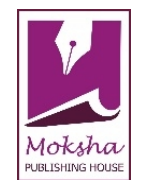

\author{
Research Article \\ www.ijrap.net
}

\title{
STUDY OF PLANT NUTRIENTS FROM 'VRIKSHA AYURVED' AND THEIR APPLICATIONS ON TULASI (OCIMUM SANCTUM) AS A CASE STUDY
}

Savita S. Nilakhe*, Madhuri Bhide, Sachin Kulkarni

Bharati Vidyapeeth Deemed University, College of Ayurved, Pune, Dhanakwadi Campus, Pune, India

Received on: 17/02/17 Accepted on: 17/04/17

\author{
*Corresponding author \\ E-mail: savitanilakhe@gmail.com
}

DOI: $10.7897 / 2277-4343.082131$

\begin{abstract}
'Vrikshayurved'- ancient Indian Sanskrit text has large variety of innovative practices regarding plant-nutrient methods. There are also many innovative methods of plantation. It has explained importance of different nutrients. The full paper reveals summary of such references. Cow-milk is the best rejuvenating \& easily endurable nutritive substance for mankind and plant. KrishnaTulasi (Ocimum sanctum) is one of the important medicinal plant used in various respiratory disorders such as bronchial asthma. Four groups comprising 6 saplings of Tulasi in each group were formed according to type of nourishment. Group-A was nourished with water $(250 \mathrm{ml})$. Group-B nourished with Cow-milk $(10 \mathrm{ml})$, Group-C nourished with Cow-ghee $(2$ $\mathrm{ml}$ ) and Group-D nourished with Cow-milk - $10 \mathrm{ml}+$ Cow-ghee $2 \mathrm{ml}$ daily. This experiment was done up to efflorescing of Ocimum sanctum which was observed after 45 days. The plant gets nourishment in its own digestible manner from soil nutrient. The test of soil reveled increase in amount of phosphorus which is directly responsible for photosynthesis. Leaf extract was examined to study changes in its chemical component 'Eugenol' with help of HPLC method. The organoleptic examination revealed that the plant nourished with milk had best growth in height, no. of leaves and luster compared to other groups. The results show Eugenol content in group B is $0.00513 \mathrm{mg} / 100 \mathrm{~g}$ and that of in group A is $0.0047 \mathrm{mg} / 100 \mathrm{~g}$.
\end{abstract}

Keywords: Eugenol, Tulasi, Ocimum sanctum, Cow Milk, Cow Ghee

\section{INTRODUCTION}

Plants are the real treasure and wealth of any country. The Mother Nature should be protected from its impairment and destruction. To conserve such precious wood riches; Indian ancient Sages have already explored many ways of nurturing the plants. There are many references which are scattered in many ancient 'Sanskrit' books. All these references are compiled in an ancient Sanskrit text 'Vriksha Ayurved' written by 'Surapala'1. There are many important methods explained in it like selection of soil; time of plantation of trees; Specific plant nutrients; the time and method of plucking the tree parts, its diseases and its Ayurvedic treatment. Such experiments should be practically observed to see its efficacy in scientific way. Also, this knowledge can benefit the tree cultivators. Hence it was decided to undertake this research work to observe the changes materialized in the plant due to specific nutrients and observe its growth.

Various Plants Nutrients-Vriksha Ayurved has explained various nutrients for plants like water, milk, ghee, animal fat etc. There is not any specific indication for any specific plant about nutrient.

Water- Water is the basic and foremost important plant nutrient. Vriksha Ayurved explains various rules of watering plants.

Rules for watering plants: The plants which are recently planted should be watered daily twice a day that is in morning and in evening. In rainy season when the soil becomes dry then only they should be watered ${ }^{2}$.

Season-wise variation- In winter season plants should be watered on alternate day. In summer, they should be watered daily. Whenever the soil appears dry it should be watered. Do not water plants in excess to avoid indigestion of plants. ${ }^{3}$

Animal Fat-Fish powder, pig fat; Meat soup; sesame; white gram; honey; cow dung and cow urine are the common important plant nutrients. Azatobactor and rizobactor are the imp bacteria which convert nitrogen in easy form. Fish has potassium in easy absorbable form. ${ }^{4}$

Milk -Milk is admired by the ancient books as the best nutrient. It is Original quality enhancer ${ }^{5}$ Also milk is the medicine of trees in many diseases. Trees are sometimes burnt due to forest fire or any mishap.

Burn cases- In case of burn of any tree by fire; the branches that caught by fire should be separated and cut off; the same sight should be irrigated by milk mixed with water. Due to this the regeneration of new leaves occurs. ${ }^{6}$

Infertility of Soil-If the soil is infertile and trees are not growing due to infertile soil; water mixed with milk should be irrigated on trees. ${ }^{7}$

Infertility of plant- Add milk to the flesh mixed water and sprinkle it on trees. This will increase productivity of plants and bears many fruits and flowers. ${ }^{8}$

Fractured trees- If the tree is fractured or broken up, it should be irrigated with Buffalo milk, rain water. It regenerates and restores growth.

Ghee- Mix Ankol (Alangium Salvifolium) fruit's pulp, honey and ghee in water. Also add deer fat and pour it on trees for better growth. ${ }^{9,10}$ irrigate the seed of mango with Ankol fruit decoction; milk and ghee together and the seed becomes viable and grows in a strong tree.

The growth can be observed by two ways i.e. external features like its height; leaves or flowers (Pharmacognosy) and another way is by testing its chemical composition (pharmacokinetic) If these experiments will enhance the active principles in the Ayurvedic herbs it can boost the medicinal value also. Hence the study was planned to get better yield of better medicinal value. Since no such study is performed yet on the plants; it was intended to do comparative study of all nutrients and compare the effect of each nutrient on the plant in Pharmacognosy and pharmacokinetic point of approach. Tulasi was selected for the experimental study. Tulasi is pungent and bitter in taste. Ushna; 
Ruksha in attribute \& excellent as expectorant. A good medicine in fever; cough, hiccup, enteric worms; chest pain due to asthama. ${ }^{10}$ It has many species. Amongst them Krishnatulasi or (Ocimum sanctum) was selected for the experimental study as it has more pungent and medicinal value. ${ }^{11}$

\section{Aim \& objectives}

To study plant nutrients like cow milk, cow ghee from 'Vrikshayurved'. To assess \& compare properties of Tulasi by using cow milk, cow ghee \& cow milk \& ghee together as a nourishing agent.

\section{MATERIALS \& METHODS}

Data was compiled from Vriksha Ayurveda by Surapala regarding different rules of plantation and different plant nutrients.

24 Tulasi saplings of 18 to $20 \mathrm{~cm}$ height (Ocimum sanctum) and 4 months old were brought from a standard herbal garden which were cultivated from same mother plant. The saplings were planted in the poyata soil which has mixture of coarse and fine particles. The earthen pots (unglazed potter's clay) having height of $30 \mathrm{~cm}$ and width of $20 \mathrm{~cm}$ were purchased for comfortable growth of plants. $3 / 4$ of the pot was filled with soil. They were grouped in four groups. Plantation ceremony was carried out on the holy occasion of prevalence of Rohini Nakshatra i.e. on 20th August 2014 in morning at $10 \mathrm{am}^{12}$

Group A- First 6 pots were grouped as group A 1; A2; A3; A4; A5; A6. All these saplings were nourished only with water. Considering the viability and natural variation of plants instead of one sapling; 6 saplings of same species (Ocimum sanctum) were planted.

Group B- Another 6 pots were grouped as group B1; B2; B3; B4; B5; B6. These plants were nourished by Cow milk. The exact dosage of plant nutrient is not mentioned in the texts like Vriksha Ayurveda. Hence it was also one of the objectives of the research to decide the dosage of milk as a small plant nutrient.

Hence 2 plants (B1 and B2) were nourished with $5 \mathrm{ml}$ of cow milk daily in the morning at 10 am along with enough quantity of water.

2 plants i.e. B3; B4 were dribbled with $10 \mathrm{ml}$ of milk. Another 2 plants i.e. B5 and B6 were nourished with $15 \mathrm{ml}$ of cow milk. Daily fresh cow milk was purchased from Katraj Milk Parlor.

Group C- Group c was nourished with cow Ghee. Cow ghee is oily and heavy substance. Also, it might coat roots. The dosage of ghee is not mentioned in Vriksha Samhita. Hence C1 and C2 Plants were poured with $1 \mathrm{ml}$ of cow ghee .C 3 and $\mathrm{C} 4$ plants were poured with $2 \mathrm{ml}$ cow ghee and C5 and C6 were nourished with 3 $\mathrm{ml}$ of cow ghee daily along with sufficient water that is around $200 \mathrm{ml}$ daily in the morning once at $10 \mathrm{am}$.

Group D- To see combined effect of Milk and Ghee both the nutrients were together poured daily to the group D saplings. D1 and D2 plants were poured with $5 \mathrm{ml}$ cow milk and $1 \mathrm{ml}$ cow ghee. D3 and D4 plants were poured with $10 \mathrm{ml}$ cow milk and 2 $\mathrm{ml}$ cow ghee. D5 and D6 plants were poured with $15 \mathrm{ml}$ of cow milk and $3 \mathrm{ml}$ of cow ghee.

All the plant nutrients were added to plant s daily at 10 am once in the morning.

The plants were watered daily from the plantation date$20 / 8 / 2014$. The roots of plants were allowed to get acquainted with the soil and environment for ten days. The project experiment was started on 1/9/2014. The pots containing plants were kept in college building terrace under the green cotton mesh to pass adequate sunrays but to avoid harsh sunrays.

\section{OBSERVATION}

The plants in group B were flourished. Height of all plants in this group was maximum amongst all the groups. The leaves were maximum in number and its surface area also was good. It had a lush green colour. This group of plants had maximum number of flowers.

Plants of group A were also good in condition. Their growth and other features were not so excellent but moderate in comparison with Group B.

The plants of group $\mathrm{C}$ and $\mathrm{D}$ which contained ghee as a nutrient had growth problem. The ghee which was poured one week earlier was visible on soil even after one week. It was inferred that biodegradation of the oily and sticky fluid like ghee is very slow. The Ghee is an excellent nutrient but it is tolerable by the shrub only once in six months and that too when it is mixed with other nutrients like cow urine. In this experiment, the daily dosage of ghee had blocked the root pours of plant. The soil was saturated with ghee which blocked the root pours. Hence the water poured daily was not absorbed in the plant. Hence the leaves of plants of this group were dried in second week. They turned into dark and purple colour and had ripened in short time. After a few days' it shredded and the plant also dried in $4^{\text {th }}$ week. As the soil was saturated due to the heavy and oily nature of ghee the plants uprooted and collapsed.

Table 1: Comparison of height of plants of all groups*

\begin{tabular}{|c|c|c|}
\hline Sr. No. & Plant Code & Height of plant in CM \\
\hline 1 & A5 & 45 \\
\hline $\mathbf{2}$ & B6 & $\mathbf{5 1}$ \\
\hline 3 & C4 & 36 \\
\hline 4 & D4 & 36 \\
\hline
\end{tabular}

Table 2: Comparison of leaves of plants of all groups*

\begin{tabular}{|c|c|c|}
\hline Sr. No. & Plant Code & Number of Leaves \\
\hline 1 & A5 & 172 \\
\hline 2 & B5 & 325 \\
\hline 3 & C3 & 89 \\
\hline 4 & D4 & 76 \\
\hline
\end{tabular}

*In each group the best fully grown Tulasi sapling was selected. It was counted for height and number of leaves.

Table 3: Comparison of weight of leaves of plants of all groups

\begin{tabular}{|c|c|c|}
\hline Group & Nutrient & Weight of leaves (in gm) \\
\hline A & Water & 30 \\
\hline B & Milk & 80 \\
\hline C & Ghee & No fresh leaves available \\
\hline D & Ghee + Milk & No Fresh leaves available. \\
\hline
\end{tabular}

Table 4: Phosphorus in Soil

\begin{tabular}{|c|}
\hline $\begin{array}{c}\text { Soil Phosphorus } \\
\text { (Pre and Post Investigations) }\end{array}$ \\
\hline Original Sample -0.5 \\
\hline Group with Milk - <10 \\
\hline Group with Ghee -49.86 \\
\hline Normal Range of Phosphorus \\
\hline Less than 7 - Very less \\
\hline 7 to 14 - Less \\
\hline 14 to $21-$ Normal \\
\hline
\end{tabular}

Eugenol-Another important test for testing the quality of Tulasi leaves is the active principle Eugenol. It is present in the Bay Leaves, Cinnamon leaves, Nutmeg, clove and Tulasi leaves. The eugenol was tested from Leaves of all four groups. Standard Eugenol (C01P060 - Ocimum sanctum) $250 \mathrm{mg}$. was brought 
from Natural Remedies private limited, Bangalore, Karnataka. (Invoice No. MU1/1516/NMF/00977)

HPLC of extract was done in comparison with eugenic oil. This procedure of HPLC was as per the reference cited in International Journal of Chemical and Physical Sciences (F. Inam, S. Deo, N. Narkhede (2014). "HPLC-UV Method Development and Quantification of Eugenol from Methanolic Extracts of Some Spices." International Journal of Chemical and Physical Sciences. Vol. 3, No. 6, pp.96-102.)

Since Milk group and water group have more number of leaves, leaves of these two groups were send to find out Eugenol percentage. Leaves weighing Minimum $25 \mathrm{gm}$ weight were required for lab analysis. Since group $\mathrm{C}$ and $\mathrm{D}$ were not having sufficient leaves for lab analysis their Eugenol percentage could not be counted.

Eugenol content of the Group B is more than Group A

\begin{tabular}{|l|l|l|}
\hline Component & Gr. A & Gr. B \\
\hline Eugenol & $0.141 \mathrm{gm}$ & $0.152 \mathrm{gm}$ \\
\hline
\end{tabular}

\section{DISCUSSION}

The Milk might have increased microbial flora in the soil, which has ultimately increased yield of Group B plants. The Milk Rejuvenates and is called as Rasayan in Ayurved for Human beings. Similarly, it has enhanced the plant growth and has flourished the Krishnatulasi plants. Even After removal of all the leaves from all plants of group A and B for lab testing, the shrub was totally bare. But the plants from Group B had again abundant leaves within 15 days compared to the leaves of Gr. A. Group C and D plants were already shrunken and dead; so those had no leaves and no change. Percentage of Phosphorus in Soil of Group B was considerably high compared to Group A and C. Phosphorus enhances the plant growth.

Vriksha Ayurved has mentioned Ghee and milk as an excellent plant nutrients but it has not explained the exact dose of the nutrients. To decide and standardize the dose of plant nutrient was also the objective of this project. The ghee can be poured in soil once in one to three months to a plant in addition to other nutrients. Ghee should not be poured daily to the plant because its excess use coats and blocks the micro root drizzles. Due to the blockage of pours the plant cannot absorb the water by osmosis. Hence the plants of group C and D were died due to lack of absorption of water. The plants nourished by milk have maximum height; no of leaves, surface area of leaves and the luster of leaves. Eugenol percent of Gr. B was more compared to other groups. The increased Phosphorus might have enhanced the plant growth by increasing photosynthesis. Milk has a good source of phosphorus which might has increased Phosphorus contents of soil. The milk might also have developed good microbial threshold in the soil. The microbes convert free nitrogen into plant nutrient in the soil. Thus, the total outcome was plants nurtured by milk had best yield of Tulasi.

\section{CONCLUSION}

Vriksha Ayurved explains many innovative methods of plantations. The nutrients like Milk \& Ghee not only provides nutrition to the plants but also are useful in its diseased conditions.
This experiment revels that Ghee if poured daily to the small shrubs coats the root drizzles and stops water absorption hence Ghee should not be poured singly and daily to the small shrubs. Amongst all the nutrients Eugenol content of the Tulasi leaves nurtured by milk was maximum. Also, the plants nurtured by milk has double yield of leaves and inflorescence in compared to plants nurtured by water and it is concluded from this research study that Milk is the best plant nutrient for Krishna Tulasi (Ocimum sanctum).

\section{ACKNOWLEDGMENTS}

Authors acknowledge Bharati Vidyapeeth Deemed University, College of Ayurved, Pune (India) and Department of Dravyaguna Vigyan, BVDU, College of Ayurved, Pune for the funds and technical support.

\section{REFERENCES}

1. Pande G., Vriksha Ayurveda of Surpala, Chaukhamba Sanskrit Series Office, Varanasi, 1st Edition, ISBN- 978-817080-337-9, 2010

2. Dikshit S.P., Vriksha Ayurveda, Kal- Aaj - Udya, Continental Publication, Pune, 2007, Pg. No. 64

3. Dikshit S.P., Vriksha Ayurveda Kal- Aaj - Udya, Continental Publication, Pune, 2007, Pg. No. 69

4. Dikshit S.P., Vriksha Ayurveda, Kal- Aaj - Udya, Continental Publication, Pune, 2007, Pg. No. 70

5. Dikshit S.P., Vriksha Ayurveda, Kal- Aaj - Udya, Continental Publication, Pune, 2007, Pg. No. 87

6. Pande G., Vriksha Ayurveda of Surpala, Chaukhamba Sanskrit Series Office, Varanasi, 1st Edition, ISBN- 978-817080-337-9, 2010, Pg. 68

7. Pande G., Vriksha Ayurveda of Surpala, Chaukhamba Sanskrit Series Office, Varanasi, 1st Edition, ISBN- 978-817080-337-9, 2010, Pg. 70

8. Pande G., Vriksha Ayurveda of Surpala, Chaukhamba Sanskrit Series Office, Varanasi, 1st Edition, ISBN- 978-817080-337-9, 2010, Pg. 71

9. Dikshit S.P., Vriksha Ayurveda Kal- Aaj - Udya, Continental Publication, Pune, 2007, Pg. No. 86

10. Dikshit S.P., Vriksha Ayurveda, Kal- Aaj - Udya, Continental Publication, Pune, 2007, Pg. No. 96

11. Kulkarni Madhuri Bhaskar, Gite Yogesh Kumar, Bhangar Santosh, Kad Ujwala, Jundhare Balasaheb, Role of Tulasi (Ocimum sanctum Linn.) Patra Swarasa on Kshudra Hikka w.s.r. to Ekal Dravya Chikitsa., Int. J. Res. Ayurveda Pharm. 2015; 6(1): 22-26

12. Mishra B., Bhavaprakasa By Bhavamishra, Vol. 1, Chaukhamba Sanskrit Sansthan, Varanasi, 8th Edition, Pg. 509

13. Dikshit S.P., Vriksha Ayurveda, Kal- Aaj - Udya, Continental Publication, Pune, 2007, Pg. No.46

\section{Cite this article as:}

Savita S. Nilakhe et al. Study of plant nutrients from 'Vriksha Ayurved' and their applications on Tulasi (Ocimum sanctum) as a case study. Int. J. Res. Ayurveda Pharm. 2017;8(Suppl 2):300$302 \mathrm{http}: / /$ dx.doi.org/10.7897/2277-4343.082131 